the Presidency College, Madras. He greatly cherished his life-long association with Prof. F. E. Fritsch, Queen Mary College, London, whom he joined in 1929. After receiving his doctorate from the University of London, he returned to the Presidency College and in 1933 took up the chair of botany in the University of Madras.

Prof. Iyengar had an insatiable interest in the study of algae, and he was a pioneer in this field in India. He is rightly regarded as the Father of Indian algology. Although his work was essentially fundamental without any immediate application, his contributions to basic knowledge are outstanding both in their thoroughness and depth. $\mathrm{He}$ was only seeking the intrinsic beauty in Nature's creation and this search gave him all the joy of his life. His meticulous observations on fertilization in Eudorina elegans, the discovery of anisogamous conjugation in Caulerpa in which the biflagellate gametes are discharged en masse in a mucilaginous matrix, the demonstration of a forcible discharge of zoospores in Trichosolen, and the establishment of an isomorphic alternation of generations in Anadyomene and Microdictyon are only a few of his many important contributions. Even to-day our information on the colonial Volvocales of India is largely based on his paper entitled "Contributions to Our Knowledge of the Colonial Volvocales of South India", published in 1933 in the Journal of the Linnean Society.

It was Prof. Iyengar's special privilege to have discovered several new algae, many of which are unique in their structure and reproduction. Among these may be mentioned Characiosiphon, Cladospongia, Cylindrocap sopsis, Dendrocystis, Ecballocystopsis, Fritschiella, Hor midiella, Pseudovalonia (Boergesenia) and Triplastrum. According to Bower, Fritschiella, a highly organized member of the Chaetophorales, is of much significance in understanding the origin of land plants. Characiosiphon is a unique genus characterized by a common envelope enclosing several discrete, naked, uninucleate protoplasts, each with a stellate chloroplast and a large pyrenoid. $\mathrm{He}$ called it a 'protocœnocyte' and considered it intermediate between a typical cœnocyte and a multicellular form. In Cylindrocapsopsis, which is of still greater interest, the quadriflagellate zoospores give rise to unicellular dwarf male and female plants. The dwarf male gives rise to two or four quadrifagellate antherozoids, while the female forms a single non-flagellated egg.

Prof. Iyengar also proposed a new concept of the origin of the filamentous condition in the green algae. He demonstrated that in Ecballocystopsis, Binuclearia and Cylindrocapsopsis the filamentous condition arises by a transverse division of the protoplasts followed by the development of new and complete walls around the daughter cells inside the wall of the mother cell. According to Pascher, it occurs in a similar way in the Myxophyceae.

Prof. Iyengar's research work was chiefly confined to the Chlorophyceae, of which the orders Volvocales and Zygnematales occupied most of his time between 1944 and 1963. Yet, as a man of wide interests, he took it as his mission to train a team of workers in other fields as well. Thus, he initiated Desikachary in the Myxophyceae; Sundaralingam, Doraiswami, Vimla Bai and Saraswathi in the Chlorophyeeae; Balakrishnan and Krishnamurthy in the Rhodophyceae; Venkataraman and Subrahmanyan in the Bacillariophycea $\theta$; Kanthamma and Janet in soil algae; and Veeraraghavan and Philipose in the limnology of Indian waters. He was also interested in the investigation of aquatic fungi and published a few papers on them.

Prof. Iyengar was a Fellow of the Linnean Society, the Indian Academy of Sciences and the National Institute of Sciences of India. He was elected one of the honorary presidents of the eighth International Botanical Congress held in 1954 at Paris, but due to ill-health he could not attend it. He was the first recipient of the Birbal Sahni Gold Medal of the Indian Botanical Society for outstanding contributions to botany and the Sundar Lal
Hora Gold Medal of the National Institute of Sciences of India. At the time of his death, Prof. Iyengar held the office of president of the International Phycological Society as well as the Indian Phycological Society.

Iyengar's sincerity of purpose, placidity of temper, genial disposition, philosophical simplicity and dedication drew the respect of all Indian scientists. His friends and students have immortalized his name by naming new genera and species after him: Iyengaria, Iyengariella, Parthasarathiella, Anabaena iyengarii, Chlamydomonas iyengarii and Scytonema iyengarii may be mentioned as examples. There is also a hyphomycetous genus Iyengarina erected by C. V. Subramanian. The Indian Botanical Society's Commemoration Volume, published in 1946 on the occasion of his sixtieth birthday, contained articles by Fritsch, Bower, Boergeson, Conrad, Gäumann, Crow, Kylin, Svedelius and many others, illustrating the high esteem in which he was held in international botanical circles.

A forceful speaker and a good sportsman, Prof. Iyengar was full of vitality and energy. He seldom missed his game of billiards. Few people excelled him in his spirit of scientific enquiry and self-denial. He was active until his death and even in his advanced years put many young people to shame by his industry and devotion.

\section{P. Maheshwari}

\section{Prof. H. J. Collins}

Writh the death on December 22, 1963, of Prof. H. J. Collins, at the age of sixty-nine, the civil and structural engineering profession in Britain has lost one of its outstanding personalities of the past thirty years. Since his retirement from the Chadwick chair of civil engineering in University College, London, in 1959, Prof. Collins had not enjoyed good health, although he religiously attended engineering reunions at University College, where he was always warmly welcomed.

Horatio John Collins, who was born in Capetown in 1894, always considered himself a Cornishman. His father was a consulting engineer, and this no doubt influenced his son's interests. He began his engineering education at the University of Birmingham in 1911, but his studies were interrupted by the First World War; during 1914-19 he served with the Royal Warwickshire Regiment. For his war-time service he was awarded an M.C.; he was demobilized in 1919 with the rank of major. On returning from the War, he graduated in 1919, and thereupon undertook research work for the Department of Scientific and Industrial Research under the direction of Prof. F. C. Lea; he took his M.Sc. in 1920. During 1920-22 he was an assistant engineer and designer to E. G. Walker, a London consulting engineer; however, in 1922, he returned to research when he once again became an assistant to Prof. Lea. In 1923 he was, for a short time, an engineerdesigner with Simon-Carves of Manchester, but in the same year he began what was to prove a long association with University College, London, when he was appointed a lecturer in structural engineering. He was promoted to senior lecturer in 1926 and to assistant professor in 1929.

As an engineer he had always had considerable sympathy with investigations in public health, and while ho was an assistant professor he designed and equipped the Chadwick Laboratory of Municipal Engineering and Hygiene in University College for postgraduate study; the first higher degree studies in public health engineering were made under his direction. This period saw the beginning of a long association of the laboratory with the Chadwick idea of "instruction in sanitary science".

In 1936 he was elected Chadwick professor in University College; he held the chair for 23 years until his retirement in 1959. During this period he encouraged the development of many research interests in his department; ho maintained a strong interest in public health engineering 
problems, as well as developing the fields of structures and stress analysis.

His aoademic work was again interrupted by war when in 1939 he joined the Royal Engineers as a Captain. In the early days of the Second World War he was stationed in Northern France, and after 1940 he worked on aero. drome construction and repair in Britain. In 1941 he was posted to Iceland, but returned to Britain again in 1942. During the Allied invasion of the Continent from 1944 until 1945 he served in France, Belgium, Germany and Holland. On returning to University College after the Second World War, he faced the very difficult task of rebuilding the bombed Chadwick Laboratory.

His interests in civil engineering were always very broad, and concerned basically with practical problems. Between the Wars he was interested in problems, among others, of the mixing of liquids and gases, cement manufacture, furnaces, penetration and impregnation of solids by liquids, steam generation, filtration, dehydration and separation of materials, and methods of tanning. In all these fields he was inventive and resourceful. In 1936 he was part. author of a book on the Principles of Road Engineering, which became a standard text.

$\mathrm{He}$ had a deep interest in the structural engineering profession, and for much of his working life he was a partner in the consulting firm of Collins and Mason. His work as a consultant brought him into contact with structural and foundation problems of all kinds, in timber, steel and reinforced concrete. He advised on the layout and design of industrial developments, including the planning of processes and complete factories. He also advised on problems of water supply and public health. In 1946 he was elected president of the Institution of Structural Engineers.

In 1929 he married Edith Mary Harvey; there is a son of the marriage. Mrs. Collins herself died recently, only two months after her husband.

\section{A. H. Chilver}

\section{NEWS and VIEWS}

\section{Royal Society Research Professorships: Dr. M. J. Lighthill, F.R.S.}

DR. M. J. LiahthiLL, who has been director of the Royal Aircraft Establishment since 1959 (Nature, 184, 151, 1959), has been appointed to a Royal Society research professorship. Dr. Lighthill is to take up his appointment on October 1 and will work in the University of London at the Imperial College of Science and Technology. He is well known for his work in non-linear problems of compressible flow, in supersonic boundary layer theory and in shock wave theory, and has made outstanding contributions in many fields of fluid dynamics as well as in more general spheres of pure and applied mathematics.

\section{Electronics at Queen's University of Belfast: \\ Prof. A. R. Boothroyd}

DR. A. R. BоотHRoyd has been appointed to the chair of electronics in the Department of Electrical Engineering of the Queen's University of Belfast. Dr. Boothroyd has been reader in electronics at the Imperial College of Science and Technology since 1959, but his association with the Department of Electrical Engineering goes back a long time. He graduated from Imperial College in 1946 and, after spending two years with the English Electric Company, Ltd., at Stafford, rejoined the College as research student to Prof. C. Cherry in 1948, working on applications of an electrolytic tank as an analogue computer in complex function theory, as related to synthesis of electric circuits. In 1951 he was appointed lecturer and rapidly made his name well known with his work on semiconductor devices and circuits. $\mathrm{He}$ has developed many industrial contacts in Britain and the United States, which he has visited several times; he was visiting professor at Berkeley during 1961 , and he is the only British member of the Semiconductor Electronics Educational Committeo-a Committee which is at present producing a series of volumes covering the whole field of semiconductor electronics: Dr. Boothroyd is an internationally acknowledged expert in this field.

\section{Electrical Engineering at Woolwich Polytechnic:}

Mr. K. B. Reed

Mr. K. B. REed has been appointed as the head of the Electrical Engineering (with Telecommunications) Depart. ment of Woolwich Polytechnic as from April l. Mr. Reed obtained a B.Sc.(Eng)(Lond) degree with first-class honours at Northampton College of Advanced Technology, and is an associate member of the Institution of Electrical Engineers. He has had industrial training and experience at Associated Electrical Industries (Woolwich), Ltd. Mr. Reed has been a principal lecturer in telecommunications at the Polytechnic for thirteen years, and has recently become a recognized teacher of the University of London. $\mathrm{He}$ is also a senior examiner in telecommunications for the City and Guilds of London Institute. His interests and publications have been in the field of random electrical fluctuations in electronic devices, and he has had much contact in this work with workers in University Departments in Britain and with establishments as far afield as Italy and the United States.

\section{Executive Secretary for the British Commonwealth Scientific Committee}

Mr. A. J. VASEY, lately technical secretary of the C.S.I.R.O. Division of Animal Health, Australia, has been seconded to the new post of executive secretary to the British Commonwealth Scientific Committee for a period of three years. The Scientific Committee, which consists of the heads of the national research organizations or their equivalents, exists to ensure the fullest possible collaboration between the Government scientific organizations of the Commonwealth. It was set up in 1946 by resolution of the British Commonwealth Scientific Official Conference as a standing committee and meets biennially. Its interim functions are carried out by a working party of deputies in London; secretariat services are provided by the British Commonwealth Scientifio Offices (London), which also operates the Commonwealth Index of Translations commenced in 1948. The Commonwerlth Committee on Fuel Research, the Commonwealth Committee on Mineral Resources and Geology (which operates the Commonwealth Geological Liaison Office), the Commonwealth Committee on Mineral Processing and the Commonwealth Collections of Microorganisms also operate under the ægis of the Committee. As full-time executive secretary, Mr. Vasey will not only administer the Committee's affairs, but will also act as liaison officer between the national bodies and, in particular, be available to help developing Commonwealth countries to obtain advice in building up their scientific organizations.

Mr. A. J. Vasey

Mr. VASTY graduated from the University of Melbourne as B.Agr.Sc. in 1926. His research career was in the agronomy of cereals and pasture plants as an officer 